ORNL-6807

HEALTH SCIENCES RESEARCH DIVISION

Waste Management Research and Development Programs

(Activity No. 613062401 NOG)

\title{
Results of the Radiological and Beryllium Verification Survey at the Sacandaga Site, Glenville, New York (SY002V)
}

\author{
R. D. Foley, W. D. Cottrell, and C. A. Johnson
}

Date issued — September 1994

Investigation Team

(Site code: SY002V)

R.D. Foley - Measurement Applications and Development Manager

W. D. Cottrell - FUSRAP Project Director

R. D. Foley, R. C. Gosslee - Field Survey Supervisors

Survey Team Members
A. C. Butler*
V. P. Patania
J. F. Allred
D. E. Rice
R. L. Coleman
D. A. Rose
R. C. Gosslee
P. F. Tiner
R. A. Mathis

*Midwest Technical, Inc.

Work performed by the

Measurement Applications and Development Group

Prepared by the OAK RIDGE NATTONAL LABORATORY

Oak Ridge, Tennessee 37831-6285

managed by

MARTIN MARIETTA ENERGY SYSTEMS, INC.

for the

U. S. DEPARTMENT OF ENERGY

under contract DE-AC05-84OR21400 



\section{DISCLAIMER}

This report was prepared as an account of work sponsored by an agency of the United States Government. Neither the United States Government nor any agency thereof, nor any of their employees, make any warranty, express or implied, or assumes any legal liability or responsibility for the accuracy, completeness, or usefulness of any information, apparatus, product, or process disclosed, or represents that its use would not infringe privately owned rights. Reference herein to any specific commercial product, process, or service by trade name, trademark, manufacturer, or otherwise does not necessarily constitute or imply its endorsement, recommendation, or favoring by the United States Government or any agency thereof. The views and opinions of authors expressed herein do not necessarily state or reflect those of the United States Government or any agency thereof. 


\section{DISCLAIMER}

Portions of this document may be illegible in electronic image products. Images are produced from the best available original document. 


\section{CONTENTS}

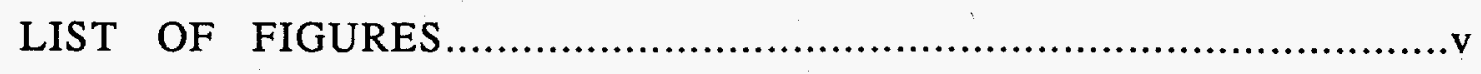

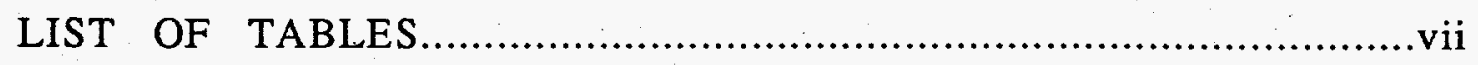

ACKNOWLEDGMENTS....................................................... ix

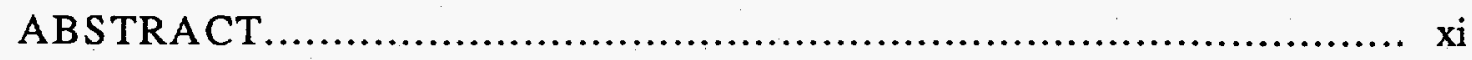

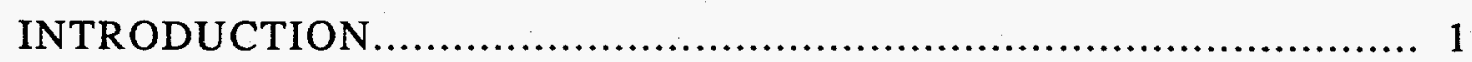

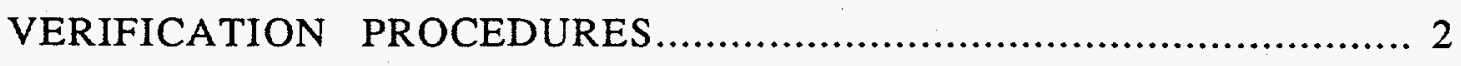

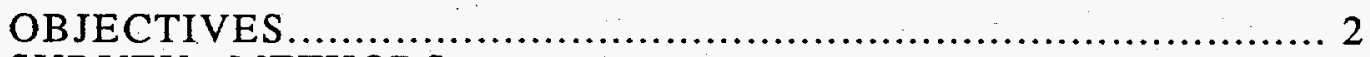

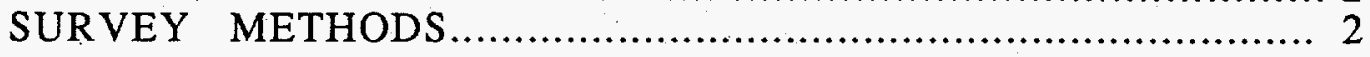

VERIFICATION SURVEY AND ANALYSIS......................................... 3

RADIOLOGICAL SURVEY RESULTS......................................... 3

BERYLLIUM SURVEY RESULTS........................................ 4

OVERCHECKS BY NEW YORK STATE ......................................... 5

CONCLUSION............................................................... 5

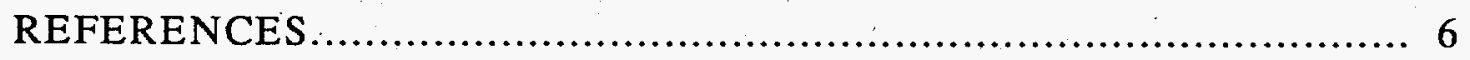





\section{LIST OF FIGURES}

1 Diagram showing general location of the Sacandaga site,

Glenville, New York

2 Diagram showing the relative locations of building $\mathbf{P}$

and the small concrete structure site at the Sacandaga site,

Glenville, New York.

3 Diagram of the gridded area over the excavated small concrete structure site, Sacandaga site, Glenville, New York.

$4 \quad$ Diagram of building $P$ at the Sacandaga site, showing gamma measurements and smear and soil sampling locations 



\section{LIST OF TABLES}

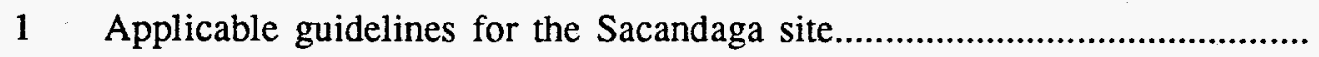

2 Background radiation levels and concentrations of selected radionuclides in soil samples taken from the Glenville, New York area...............................

3 Concentrations of radionuclides and beryllium in soil samples from the Sacandaga site

$4 \quad$ Samples taken in building $P$ for the verification of the Sacandaga site showing sample locations and beryllium results. 



\section{ACKNOWLEDGMENTS}

Research for this project was sponsored by the Office of Naval Reactors, U. S. Department of Energy, under contract DE-AC05-OR21400 with Martin Marietta Energy Systems, Inc. The authors wish to acknowledge the contributions of W. D. Cottrell, D. A. Roberts, D. A. Rose,, P. Brimer, J. Lovegrove and T. R. Stewart of the Measurement Applications and Development Group for participation in the sample preparation and analyses, editing, graphics, and reporting of data for this survey. The surveying assistance of the staff on the survey team is also gratefully acknowledged. The operational and technical assistance of M. J. McGeoch and G. A. Racine of the Knolls Atomic Power Laboratory is gratefully acknowledged. 



\begin{abstract}
At the request of the U.S. Department of Energy (DOE), a team from Oak Ridge National Laboratory conducted an independent verification radiological and non-radioactive beryllium survey at the Sacandaga site, located on Sacandaga Road, Glenville, New York following limited remediation of the site by Allwash of Syracuse, Inc. At the time of this survey, only building $P$ was still standing. A small concrete structure at the east end of the property had been demolished and the debris hauled away, leaving only a pit. The purpose of the survey, conducted between April and August 1993, was to confirm the success of the remedial actions performed to remove any beryllium concentrations or radioactive materials in excess of the identified guidelines. The verification survey included surface gamma scans and gamma readings at 1 meter indoors and outdoors, alpha and beta scans inside building $P$, and the collection of soil, dust and debris samples and smears for radionuclide and beryllium analyses.
\end{abstract}

Results of the survey demonstrated that all radiological and beryllium measurements on the property were within applicable DOE guidelines. Based on all data collected, the Sacandaga Site, Glenville, New York, conforms to all applicable radiological and non-radioactive beryllium guidelines established for this site by DOE and approved by the State of New York. 


\section{RESULTS OF THE RADIOLOGICAL and BERYLLIUM VERIFICATION SURVEY at the SACANDAGA SITE, GLENVILLE, NEW YORK (SY002V)*}

\section{INTRODUCTION}

The Sacandaga site, located on Sacandaga Road, Glenville, New York, was operated by the General Electric Company for the Atomic Energy Commission (AEC) between 1947 and 1951. AEC-sponsored research at the site involved physics studies and sodium technology development in support of breeder reactor design and other AEC programs. Work was also conducted using non-radioactive beryllium. The general location of the site is shown in Fig. 1.

It is the policy of the U.S. Department of Energy (DOE) to verify that environmental conditions related to DOE activities at formerly used sites and facilities comply with current DOE guidelines. At the request of the Office of Naval Reactors through the Office of Remedial Action and Waste Technology, a site visit and preliminary scoping survey of the portion of the site that had contained the process and associated service buildings (5-6 acres) was conducted by Oak Ridge National Laboratory in July 1988.1 When the survey was conducted, building P (the former critical facility building) and a small concrete structure at the east end of the property were the only aboveground structures still standing: Figure 2 is a diagram of the site showing the relative locations of building $\mathrm{P}$ and the small concrete structure. In order to provide a more comprehensive assessment of the site, it was recommended that a second survey including subsurface investigations be conducted. A radiological characterization survey covering about 10 acres of the site was performed between August and October 1989.2 Based on the results of that survey, a supplementary survey for beryllium was conducted within the small concrete structure in February 1991.2 Additional beryllium sampling in building P was performed in April 1993. Representatives of the New York State Departments of Environmental Conservation and Health also participated in the site characterization studies.

Survey results indicated that no detectable residual radioactivity from former Sacandaga site research operations was present. All radiation levels and radionuclide concentrations were within DOE guidelines. Although concentrations of beryllium in samples from across the site were consistent with natural background levels, residual beryllium was found in samples of the gravel floor and subfloor soil from within the small concrete structure. Although there is no explicit Occupational Safety and Health Administration standard for allowable areal concentrations of beryllium, the concentration of beryllium identified in the small concrete structure exceeded the site specific guidelines which were developed (Table 1), and limited remedial action was planned. 3

Remedial actions at the site, which included removal of the small concrete structure, were conducted and completed in August 1993 by Allwash of Syracuse, Inc. 4 Samples

\footnotetext{
${ }^{*}$ The survey was performed by members of the Measurement Applications and Development Group of the Health Sciences Research Division of Oak Ridge National Laboratory under DOE contract DE-AC05-84OR21400.
} 
were taken to demonstrate that the residual beryllium had been removed. In keeping with the DOE policy to assign an independent verification contractor, concurrent with the remedial actions, ORNL performed an independent survey to confirm the success of the remedial actions. Soil samples were taken in the vicinity of the former small concrete structure and outside of building P. Additionally, radiological surveys were conducted inside building $\mathrm{P}$ in areas that became accessible as a result of the remedial actions. This report describes the verification survey and documents the results.

\section{VERIFICATION PROCEDURES}

\section{OBJECTIVES}

The objective of the verification activities was to confirm that the remedial action reduced beryllium levels to within the DOE guidelines. In addition, radiological surveys were conducted in areas made accessible by the remedial activities to confirm that these areas also met DOE guidelines. Applicable guidelines, which were established by the DOE and approved by New York State, are shown in Table 1.

\section{SURVEY METHODS}

The post-remedial action survey was performed on this property as described for a generic site. 5 This survey consists of ground-level beta-gamma measurements, surface gamma measurements, and systematic soil and miscellaneous material sampling.

Using a portable gamma scintillation meter, ranges of measurements were recorded for areas of the property surface and one meter above the surface, as well as inside the structure. To assure identification of any possible remaining beryllium following cleanup, visual inspection of surfaces for lingering dirt and/or dust accompanied the survey activities. Smears and/or samples of dust and debris were collected at systematic locations.

Systematic soil samples were obtained from an area outside the northwest corner of building $\mathrm{P}$ and from established grid coordinates in the small concrete structure area (Fig. 3).

The following procedures were performed to assess the success of the beryllium cleanup activities and for the additional radiological surveys:

Beryllium

- visual inspections for dust on all indoor surfaces;

- $\quad$ collection and analysis of smears and miscellaneous samples on selected building P surfaces including walls, floors, and beams;

- collection of soil and debris samples at the small concrete structure site, now excavated. 


\section{$\underline{\text { Radiological }}$}

- alpha and beta-gamma scans of all structural areas, including areas previously inaccessible;

- Radiological surface measurements near the soil surfaces in the hole remaining after demolition of the small concrete structure prior to backfilling;

- collection and analysis of smears taken from selected areas inside building $\mathrm{P}$ to determine radionuclide content;

- collection and analysis of soil samples taken from areas outside building P and in the excavated small concrete structure area.

\section{VERIFICATION SURVEY AND ANALYSIS}

Typical background radiation levels for the Glenville, New York, area are listed in Table 2. The data are provided for purposes of comparison with the survey results presented in this section.

Direct measurement results presented in this report are gross readings; background radiation levels have not been subtracted. Similarly, background radiation levels have not been subtracted from radionuclide concentrations measured in environmental samples.

\section{RADIOLOGICAL SURVEY RESULTS}

\section{Building $\mathrm{P}$}

Indoors: Following the removal of all equipment and miscellaneous materials inside, a general gamma scan was conducted of the interior concrete room and covered port area. The survey included alpha, gamma, and beta-gamma scans, as well as smears of the rail supports, ceiling and " $\mathrm{I}$ " beams, walls and floors. One elevated measurement was found in a spot on the floor near the north wall. This spot was within applicable DOE guidelines; however, consistent with the principle of ALARA (as low as reasonably achievable), it was remediated by chipping up the concrete, and verified as clean by ORNL during this survey (see Fig. 4).

The gamma scan resulted in measurements ranging from $6-11 \mu \mathrm{R} / \mathrm{h}$ both at the surface and at one meter inside building P (Fig. 4). These values are comparable to the background levels recorded for the area (Table 2).

Smears were taken from the floors, walls, and ceiling beams, and counted for alpha and beta radioactivity. No structural transferable alpha or beta-gamma radioactivity above guidelines was observed. Maximum transferable activities of $40 \mathrm{dpm} / 100 \mathrm{~cm}^{2}$ beta-gamma, and $6 \mathrm{dpm} / 100 \mathrm{~cm}^{2}$ alpha were measured in smears taken from inside the structure. All activities are well below DOE guidelines for surface radioactivity levels of $1000 \mathrm{dpm} / 100$ $\mathrm{cm}^{2}$ transferable uranium alpha or beta-gamma activity (Table 1).

Some of these smears, identified as sample numbers VT200-VT208, were also analyzed for beryllium as discussed below. 
Outdoors: Elevated gamma readings at the northeast corner on the outside of the building were reported by the State of New York. Surface and auger samples taken earlier by ORNL from this area, when analyzed, indicated natural background levels. The area was a mound of debris which appeared to contain chips of local shale (Fig. 4). Gamma readings of $15-18 \mu \mathrm{R} / \mathrm{h}$ were measured by ORNL in the area, a measurement probably influenced by the presence of the shale.

Three soil samples (VS225-VS227) were taken at 6 inch intervals in the mound of debris at the northeast corner of building P (Fig. 4) and analyzed for uranium, radium and thorium. Radionuclide concentrations of $238 \mathrm{U}$ in both surface and subsurface soil ranged from 1.5 to $1.9 \mathrm{pCi} / \mathrm{g}$. These concentrations are well below DOE guidelines for this site and are comparable to background concentrations for the area (Table 1). Concentrations ranging from 1.2 to $1.4 \mathrm{pCi} / \mathrm{g}$ for $226 \mathrm{Ra}$, and from 1.2 to $1.6 \mathrm{pCi} / \mathrm{g}$ for $232 \mathrm{Th}$ are also comparable to background concentrations.

\section{Small Concrete Structure Area}

The small concrete structure had been demolished and debris and all soil exceeding beryllium guidelines had been removed. Grid coordinates were established for scanning and sampling the soil in and around the pit left in the excavated area $\left(-3600 \mathrm{ft}^{2}\right)$.

Gamma levels in the area ranged from $9-20 \mu \mathrm{R} / \mathrm{h}$ at one meter above the excavated area. In a general surface scan of the pit, gamma ranges were from $12-24 \mu \mathrm{R} / \mathrm{h}$ from the bottom of the pit to the rim of soil at the top (Fig. 3). A maximum of $30 \mu \mathrm{R} / \mathrm{h}$ was measured on contact with the walls. These values are typical of those found previously and are identified in association with a material resembling coal ash. Coal ash, as well as many other natural substances, typically exhibits elevated gamma exposure rates when compared to surrounding soils. The results of radionuclide analysis of the soil samples (see below) substantiate the probability of a source for the general elevations other than Sacandaga site research operations (i.e., naturally occurring $40 \mathrm{~K}$; an elevated range of 15 to $32 \mathrm{pCi} / \mathrm{g} 40 \mathrm{~K}$ was also measured in the samples).

Soil samples were systematically taken from the gridded area of the small concrete structure and analyzed for radionuclide concentrations. The maximum concentrations (surface and subsurface samples) for $226 \mathrm{Ra}$ and $232 \mathrm{Th}$ were $1.9 \mathrm{pCi} / \mathrm{g}$ and $1.8 \mathrm{pCi} / \mathrm{g}$ respectively. Both are comparable to background values for the area. A maximum of 2.5 $\mathrm{pCi} / \mathrm{g}$ was measured for $238 \mathrm{U}$, also comparable to background levels and well below DOE guidelines for this site. Analytical results are listed in Table 3, and sample locations are shown on Fig. 3.

\section{BERYLLIUM SURVEY RESULTS}

\section{Building $\mathrm{P}$}

Analysis of the smears that were taken in April 1993 from inside building $P$ indicated non-radioactive beryllium concentrations that were below, but close to guideline values. Therefore, on the basis of the ALARA policy, remediation of the surfaces within the structure was conducted by Allwash of Syracuse, Inc. and additional sampling was 
done in August. Table 4 shows the results from both sampling intervals.

In August, another visual inspection was conducted for dust within the building, as well as the collection of smears and samples from all surfaces including those from previously inaccessible areas. Beryllium concentrations in the smears ranged from 0.45 to $0.85 \mu \mathrm{g} / \mathrm{ft}^{2}$. These values are well below the guidelines for beryllium in dust. Fig. 4 shows the approximate location of the sampling in building P. Results of the analysis indicate beryllium content below the guidelines for beryllium in dust $(2 \mu \mathrm{g} / \mathrm{ft} 2)$ and soil/debris $(13 \mu \mathrm{g} / \mathrm{g})$. See Table 1 for identified guidelines for the Sacandaga site.

\section{Small Concrete Structure Area}

Soil samples were taken within the gridded area of the excavated small concrete structure and analyzed for residual beryllium in addition to the analysis for radionuclides. Each sample was split into two parts and given odd and even numbers. The odd numbered samples were analyzed for beryllium only. Results of analysis are detailed in Table 4. Beryllium concentrations ranged from $0.62 \mu \mathrm{g} / \mathrm{g}$ to $3.2 \mu \mathrm{g} / \mathrm{g}$ in these samples. Natural beryllium in soil concentrations average from 0.6 to $6.0 \mu \mathrm{g} / \mathrm{g}$ as reported in several soil geochemistry surveys. The maximum concentration was found in sample VS214 (taken from the excavated pit) as shown in Table 4 and located on Fig. 3. All of the samples were well below the guidelines for concentrations of beryllium in soil of $13 \mu \mathrm{g} / \mathrm{g}$.

\section{OVERCHECKS BY NEW YORK STATE}

Representatives of the New York State Departments of Environmental Conservation and Health conducted additional independent overcheck surveys on August 27 and September 1, 1993, respectively, for residual radioactivity and beryllium. The results of these surveys showed no radioactivity above natural background levels and all beryllium concentrations were well below the established criteria. 6

\section{CONCLUSION}

Results of this independent verification survey confirm that no detectable residual radioactivity from former research operations remain at the Sacandaga site. All radiation levels and radionuclide concentrations are consistent with radionuclide concentrations typical of natural soil and coal ash and are well below DOE guidelines established for this site.

The results of this survey also confirm that the concentration of non-radioactive, elemental beryllium at the site following remediation is well below DOE guidelines established for the site. All measured concentrations of beryllium in outdoor soil and indoor dust/debris were within the range of natural beryllium in soil and below guidelines established for the site.

Based on all data collected, the Sacandaga Site, Glenville, New York, conforms to all applicable radiological and non-radioactive beryllium guidelines established for the site by the DOE and approved by the State of New York. 


\section{REFERENCES}

1. W. D. Cottrell, R. D. Foley, and R. F. Carrier, Preliminary Site Survey Report for the Sacandaga Site, Glenville, New York, ORNL/RASA-88/102, Martin Marietta Energy Systems, Inc., Oak Ridge Natl Lab., March 1989.

2. R. D. Foley, W. K. Cottrell, R. F. Carrier, Results of the Radiological Survey at. the Sacandaga Site, Glenville New York, ORNL-6638, Martin Marietta Energy Systems, Inc., Oak Ridge Natl. Lab., August 1992.

3. U.S. Department of Energy, Remedial Action Plan for Sacandaga Site, Glenville, New York, August 1992.

4. Knolls Atomic Power Laboratory, Inc., Post Remedial Action Report for the Sacandaga Site Property in Glenville, New York, KAPL-4804, August 1994.

5. T. E. Myrick, B. A. Berven, W. D. Cottrell, W. A. Goldsmith, and F. F. Haywood, Procedures Manual for the ORNL Radiological Survey Activities (RASA) Program, ORNL/TM-8600, Martin Marietta Energy Systems, Inc., Oak Ridge Natl. Lab., April 1987.

6. New York State Department of Environmental Conservation, correspondence from Merges to A.R. Seepo, U.S. Department of Energy, Radiological/Environmental Control and Safety Division, Schenectady, New York, February 1994. 


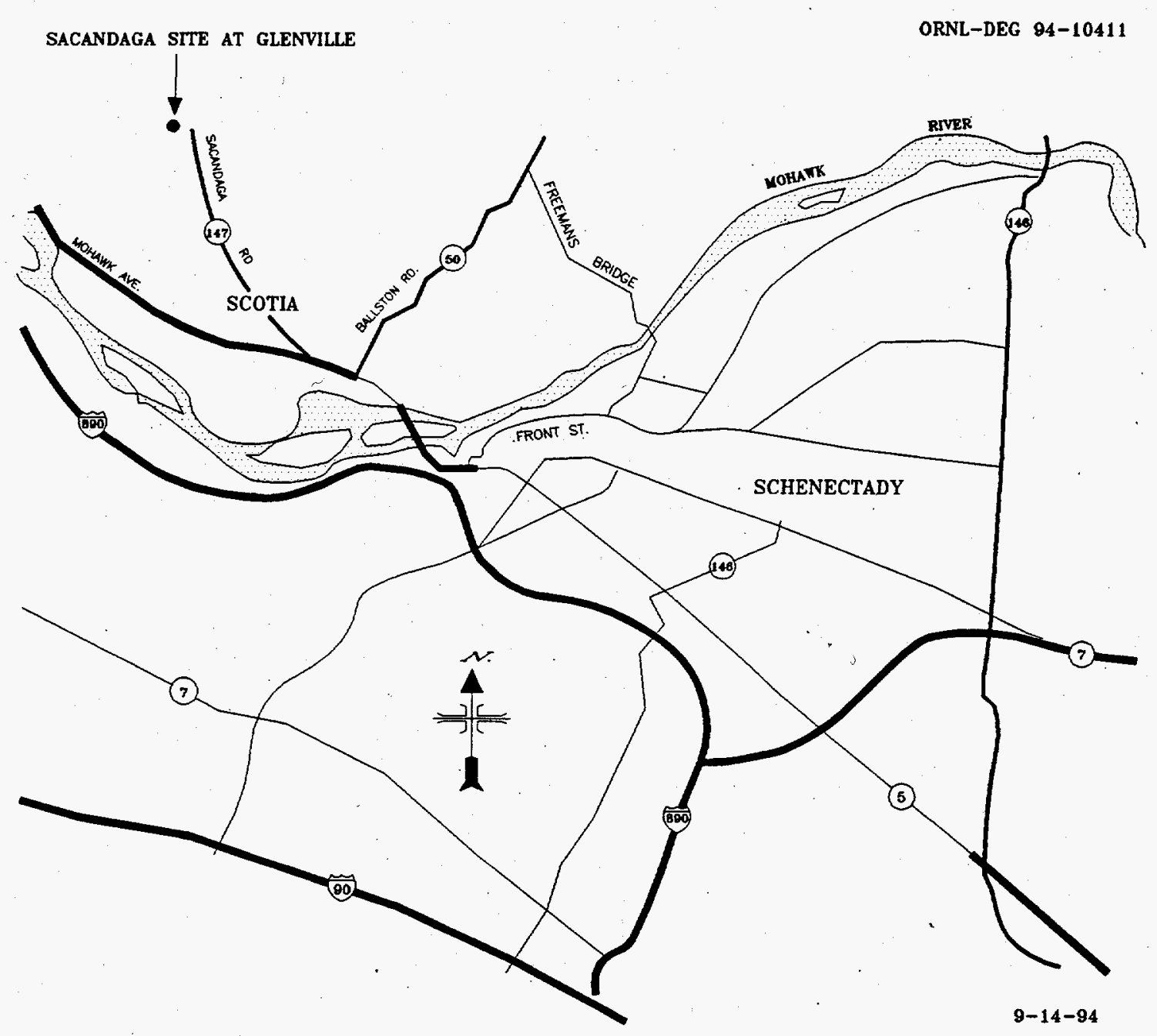

Fig. 1. Diagram showing general location of the Sacandaga site, Glenville, New York. 


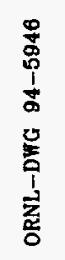

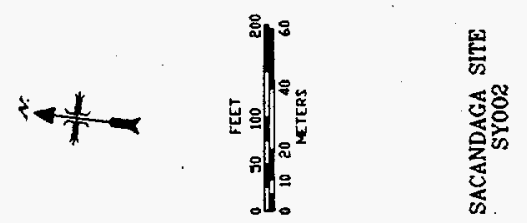

ت્ّ

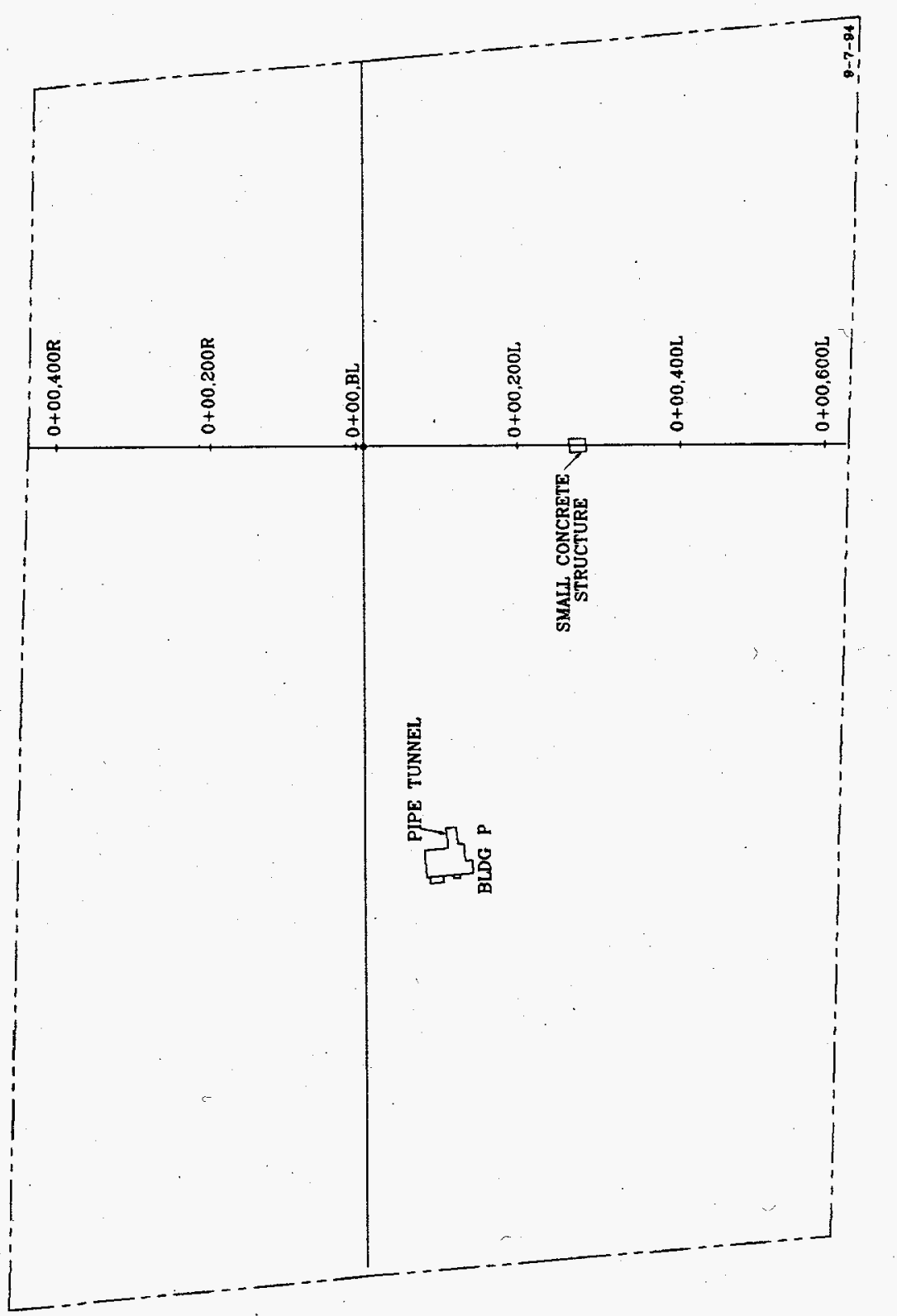

米

늘

के

范

覀

巳્

ซ

$\infty$

音

ธ

.

葛

हैं

윰 


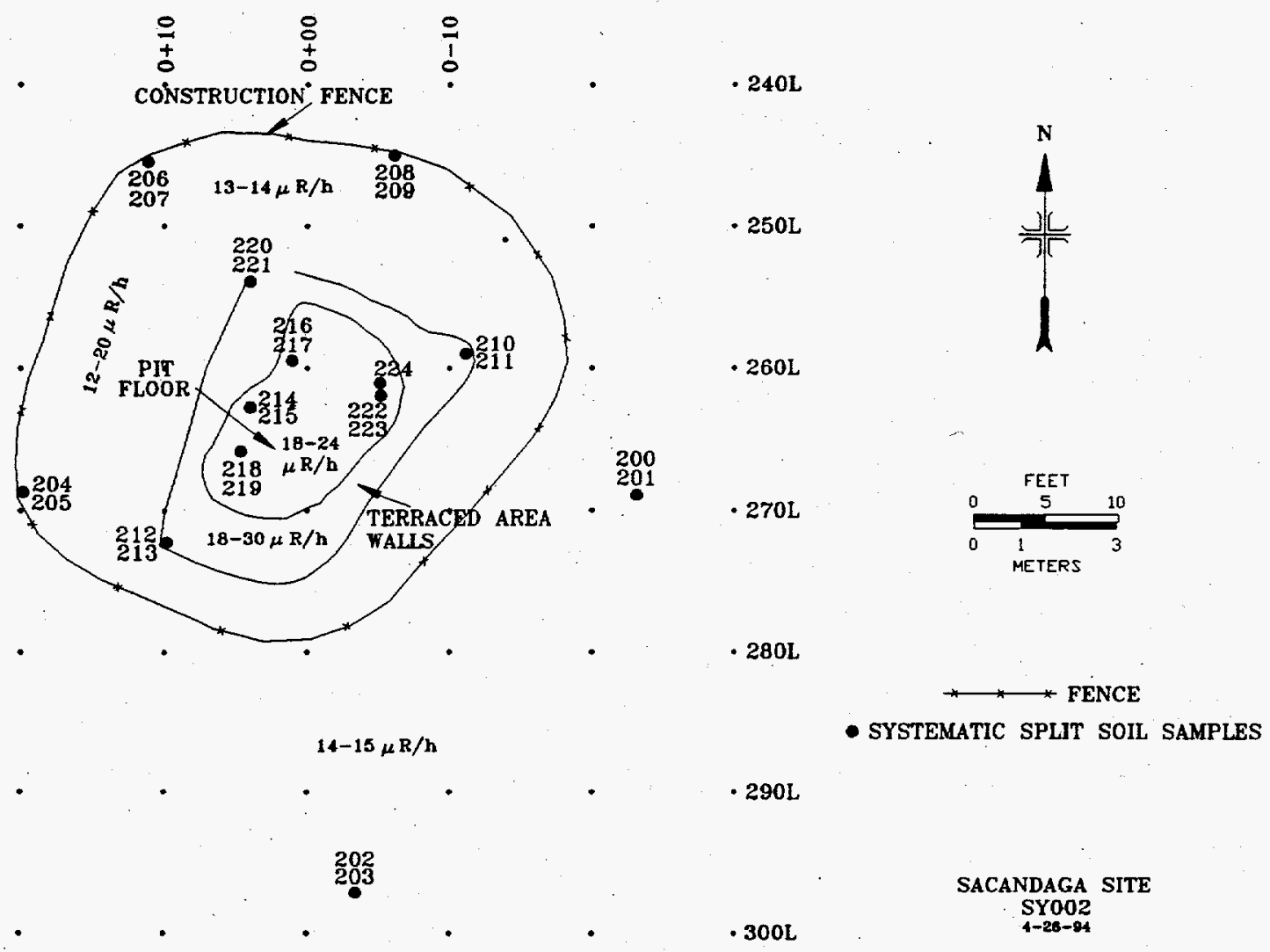

Fig. 3. Diagram of the gridded area over the excavated small concrete structure site, Sacandaga site, Glenville, New York. Soil samples and gamma measurements are shown. Even numbered samples were analyzed for radionuclides, odd for beryllium. 
ORNL-DWG 94-5945

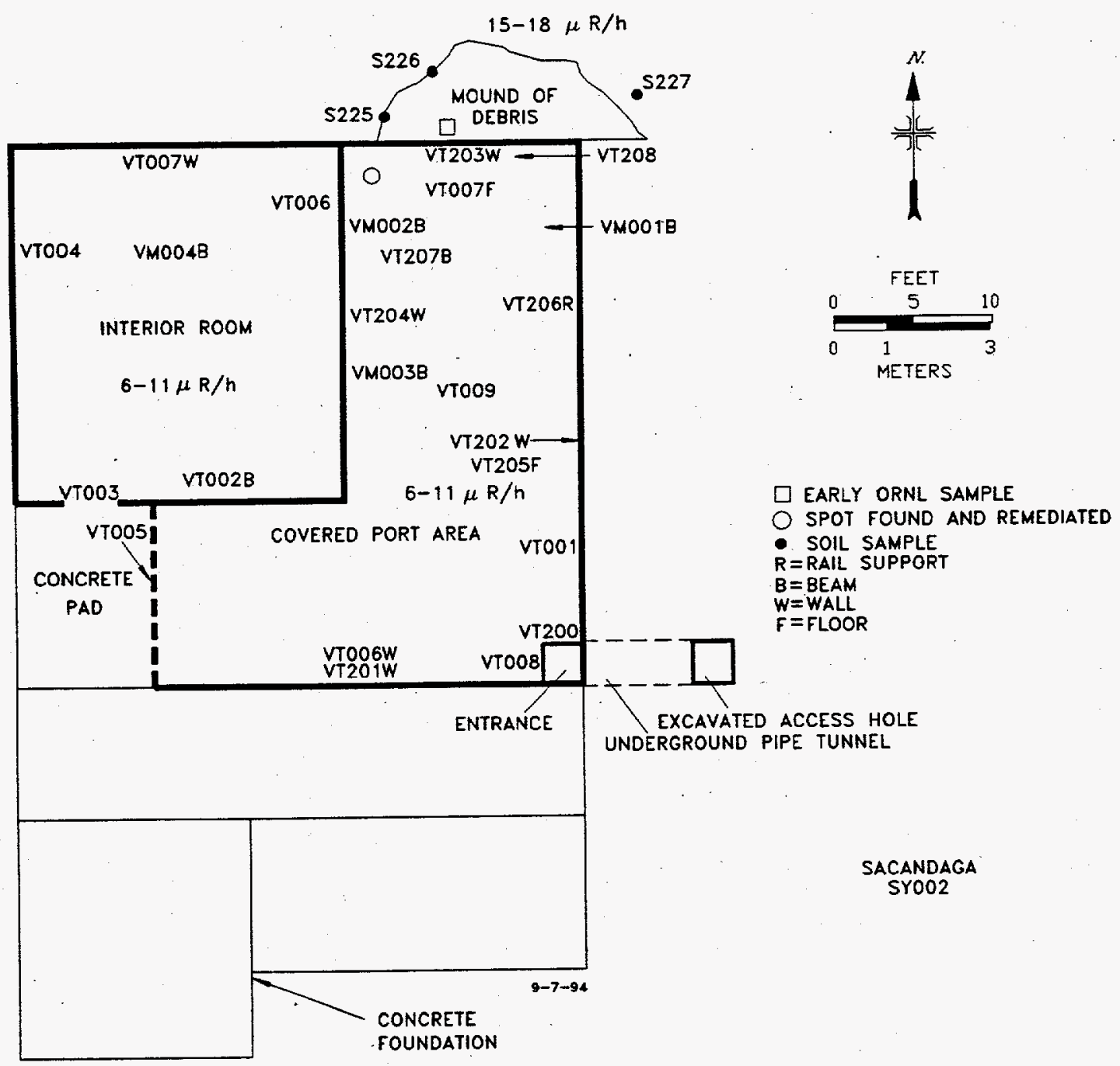

Fig. 4. Diagram of building $P$ at the Sacandaga site, showing gamma measurements and smear and soil sampling locations. 
Table 1. Applicable Guidelines for the Sacandaga site

\begin{tabular}{|c|c|}
\hline Mode of exposure & Guideline value \\
\hline $238 \mathrm{U}$ in soil & $35 \mathrm{pCi} / \mathrm{g}$ \\
\hline $\begin{array}{l}238 \mathrm{U} \text { in indoor dust, } \\
\text { removablealpha activity }\end{array}$ & $1000 \mathrm{dpm} / 100 \mathrm{~cm}^{2}$ \\
\hline $\begin{array}{c}238 \mathrm{U} \text { indoors as fixed plus } \\
\text { removable alpha surface } \\
\text { contamination }\end{array}$ & $5000 \mathrm{dpm} / 100 \mathrm{~cm}^{2}$ \\
\hline 238U in air & $2 \times 10^{-12} \mu \mathrm{Ci} / \mathrm{mL}$ \\
\hline $\begin{array}{l}\text { Beta-gamma } \\
\text { dose rate at } 1 \mathrm{~cm} \text { from } \\
\text { the surface averaged over } \\
\text { not more than } 1 \mathrm{~m}^{2} \text { area }\end{array}$ & $0.2 \mathrm{mrad} / \mathrm{h}$ \\
\hline $\begin{array}{c}\text { Maximum beta-gamma } \\
\text { dose rate at } 1 \mathrm{~cm} \text { from } \\
\text { the surface over any } \\
100-\mathrm{cm}^{2} \text { area. }\end{array}$ & $1.0 \mathrm{mrad} / \mathrm{h}$ \\
\hline $\begin{array}{l}\text { Gamma exposure rate indoors } \\
\text { at } 1 \mathrm{~m} \text { above the surface } \\
\text { above background }\end{array}$ & $20 \mu \mathrm{R} / \mathrm{h}$ \\
\hline $\begin{array}{l}\text { Beryllium in removable } \\
\text { surface dust }\end{array}$ & $2 \mu \mathrm{g} / \mathrm{ft}^{2}$ \\
\hline $\begin{array}{l}\text { Beryllium in air } \\
\text { 8-hr average } \\
\text { - acceptable ceiling } \\
\text { - never to be exceeded }\end{array}$ & $\begin{array}{c}2 \mu \mathrm{g} / \mathrm{m}^{3} \\
5 \mu \mathrm{g} / \mathrm{m}^{3} \\
25 \mu \mathrm{g} / \mathrm{m}^{3}\end{array}$ \\
\hline Beryllium in soil & $13 \mu \mathrm{g} / \mathrm{g}$ \\
\hline${ }^{137} \mathrm{Cs}$ in soil & $34 \mathrm{pCi} / \mathrm{g}$ \\
\hline
\end{tabular}


Table 2. Background radiation levels and concentrations of selected radionuclides in soil samples taken from the Glenville, New York area

Type of radiation measurement

Radiation level or or sample radionuclide concentration ${ }^{a}$

Range Average

Gamma exposure rate at

$-$

$8-10$

Gamma exposure rate at $1 \mathrm{~m}$ above

floor or ground surface $(\mu R / h)^{b}$

Concentration of radionuclides

in soil (pCi/g dry wt )a

226 Ra

$232 \mathrm{Th}$

$238 \mathrm{U}$
0.83-0.98

$0.81-0.95$

$0.94-1.3$
0.93

0.89

1.2

$a$ Values and soil samples (SY075-SY077) were obtained from three undesturbed locations near the Sacandaga site in Glenville. 2

$b$ Exposure rates obtained from four locations in the Albany area (ORNL/RASA-87/117, Feb 1988). 
Table 3. Concentrations of radionuclides and beryllium in soil samples from the Sacandaga site

\begin{tabular}{|c|c|c|c|c|c|}
\hline \multirow{2}{*}{$\begin{array}{l}\text { Sample } \\
\text { number }\end{array}$} & \multirow{2}{*}{$\begin{array}{c}\text { Depth } \\
\text { (cm) }\end{array}$} & \multicolumn{3}{|c|}{ Radionuclide concentration $(\mathrm{pCi} / \mathrm{g}) b$} & \multirow{2}{*}{$\begin{array}{l}\mathrm{Be} \\
\mu \mathrm{g} / \mathrm{g}\end{array}$} \\
\hline & & $238 \mathrm{U}$ & $226 \mathrm{Ra}$ & $232 \mathrm{Th}$ & \\
\hline \multicolumn{6}{|c|}{ Small Concrete Structure Samplesc } \\
\hline $\begin{array}{l}\text { VS200 } \\
\text { VS201a }\end{array}$ & $0-15$ & $1.6 \pm 0.4$ & $1.4 \pm 0.2$ & $1.4 \pm 0.3$ & $\begin{array}{l}d \\
1.1\end{array}$ \\
\hline $\begin{array}{l}\text { VS202 } \\
\text { VS203 }\end{array}$ & $0-15$ & $1.4 \pm 0.4$ & $1.2 \pm 0.1$ & $1.02 \pm 0.2$ & $\begin{array}{l}d \\
0.82\end{array}$ \\
\hline $\begin{array}{l}\text { VS204 } \\
\text { VS205 }\end{array}$ & $0-15$ & $2.2 \pm 0.5$ & $1.1 \pm 0.2$ & $1.2 \pm 0.2$ & $\begin{array}{l}d \\
0.72\end{array}$ \\
\hline $\begin{array}{l}\text { VS206 } \\
\text { VS207 }\end{array}$ & $0-15$ & $<1.5$ & $1.02 \pm 0.1$ & $0.86 \pm 0.2$ & $\begin{array}{l}d \\
0.72\end{array}$ \\
\hline $\begin{array}{l}\text { VS208 } \\
\text { VS209 }\end{array}$ & $0-15$ & $2.1 \pm 0.8$ & $1.02 \pm 0.1$ & $0.87 \pm 0.2$ & $\begin{array}{l}d \\
0.62\end{array}$ \\
\hline $\begin{array}{l}\text { VS } 210 \\
\text { VS211 }\end{array}$ & $0-15$ & $2.5 \pm 1.0$ & $1.3 \pm 0.2$ & $1.2 \pm 0.2$ & $\begin{array}{l}d \\
0.72\end{array}$ \\
\hline $\begin{array}{l}\text { VS212 } \\
\text { VS213 }\end{array}$ & $0-15$ & $1.9 \pm 0.4$ & $1.9 \pm 0.2$ & $1.8 \pm 0.4$ & $\begin{array}{l}d \\
0.96\end{array}$ \\
\hline $\begin{array}{l}\text { VS214 } \\
\text { VS215 }\end{array}$ & $0-15$ & $1.4 \pm 0.5$ & $1.6 \pm 0.12$ & $1.4 \pm 0.2$ & $\begin{array}{l}d \\
3.2\end{array}$ \\
\hline $\begin{array}{l}\text { VS216 } \\
\text { VS } 217\end{array}$ & $0-15$ & $1.8 \pm 0.8$ & $1.6 \pm 0.1$ & $1.4 \pm 0.2$ & $\begin{array}{l}d \\
0.88\end{array}$ \\
\hline $\begin{array}{l}\text { VS218 } \\
\text { VS219 }\end{array}$ & $0-15$ & $1.8 \pm 0.5$ & $1.7 \pm 0.1$ & $1.6 \pm 0.2$ & $\begin{array}{l}d \\
2.6\end{array}$ \\
\hline $\begin{array}{l}\text { VS220 } \\
\text { VS221 }\end{array}$ & $0-15$ & $1.7 \pm 0.3$ & $1.5 \pm 0.2$ & $1.6 \pm 0.3$ & $\begin{array}{l}d \\
0.76\end{array}$ \\
\hline $\begin{array}{l}\text { VS222 } \\
\text { VS223 }\end{array}$ & $0-15$ & $1.5 \pm 0.4$ & $1.5 \pm 0.2$ & $1.5 \pm 0.3$ & $\begin{array}{l}d \\
0.88\end{array}$ \\
\hline VS224 & $0-15$ & $1.7 \pm 0.7$ & $1.5 \pm 0.1$ & $1.5 \pm 0.2$ & $d$ \\
\hline
\end{tabular}


Table 3. (continued)

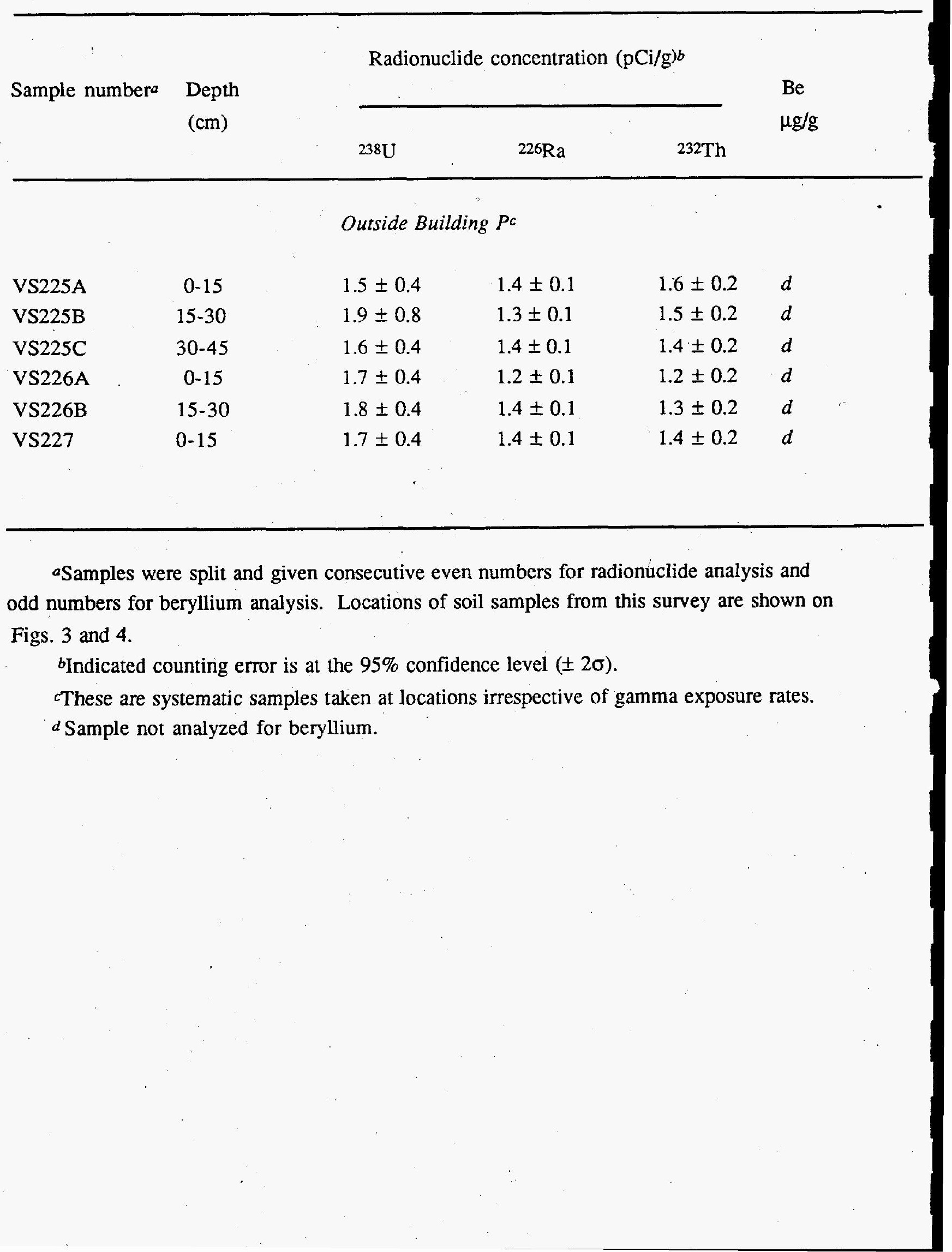


Table 4. Samples taken in Building $P$ for the verification of the Sacandaga site showing sample locations and beryllium results

\begin{tabular}{|c|c|c|c|c|}
\hline $\begin{array}{l}\text { Sample } \\
\text { ID }^{\mathbf{a}}\end{array}$ & $\begin{array}{c}\mathrm{Be} \\
(\mu \mathrm{g} / \mathrm{g}) \\
(\mu \mathrm{g})^{*}\end{array}$ & $\begin{array}{l}\text { Be/areab } \\
\left(\mu \mathrm{g} / \mathrm{ft}^{2}\right)\end{array}$ & Location & Location detail \\
\hline \multicolumn{5}{|c|}{ April 1993 samples } \\
\hline VM001 & $<0.25$ & NA & covered port & Crane "I" beam E side \\
\hline VM002 & 0.35 & NA & covered port & Crane "I "beam W side \\
\hline VM003 & 0.36 & NA & covered port & $\begin{array}{l}\text { Center, crane "I" beam } \\
\text { W side }\end{array}$ \\
\hline VM004 & $<0.25$ & NA & interior room & Center north beam \\
\hline VT001 & $<0.20^{*}$ & $<1.8$ & covered port & $\begin{array}{l}\text { E wall, } 6 \mathrm{ft} \text { from floor, } \\
10 \mathrm{ft} \text { from } \mathrm{S} \text { wall }\end{array}$ \\
\hline VT002 & $<0.20^{*}$ & $<1.8$ & interior room & Center of $S$ beam \\
\hline VT003 & $<0.20^{*}$ & $<1.8$ & interior room & Hole above door, $S$ wall \\
\hline VT004 & $<0.20^{*}$ & $<1.8$ & interior room & $\begin{array}{l}\mathrm{W} \text { Wall } 6 \mathrm{ft} \text { from floor, } \\
3 \mathrm{ft} \text { from } \mathrm{N} \text { wall }\end{array}$ \\
\hline VT005 & $<0.20^{*}$ & $<1.8$ & West wall (outside) & Hole over drive-in door \\
\hline VT006 & $<0.20^{*}$ & $<1.8$ & covered port & $\begin{array}{l}\text { S Wall, center, } 6 \mathrm{ft} \text { from } \\
\text { floor }\end{array}$ \\
\hline VT007 & $<0.20^{*}$ & $<1.8$ & covered port & $\begin{array}{l}\text { N Wall, center, } 6 \mathrm{ft} \text { from } \\
\text { floor }\end{array}$ \\
\hline VT008 & $<0.20^{*}$ & $<1.8$ & covered port & Tunnel entrance, SE \\
\hline VT009 & $<0.20^{*}$ & $<1.8$ & covered port & $\begin{array}{l}\text { corner } \\
\text { Center of floor }\end{array}$ \\
\hline \multicolumn{5}{|c|}{ August 1993 samples } \\
\hline VT200c & 0.11 & 0.50 & covered port & \multirow{9}{*}{$\begin{array}{l}3.5 \mathrm{ft} \mathrm{W}, 5.5 \mathrm{ft} \mathrm{N} \text { of } \mathrm{SE} \\
\text { corner } \\
\text { Center } \mathrm{S} \text { wall, } 6 \mathrm{ft} \text { from floo } \\
\text { Center E wall, } 6.5 \mathrm{ft} \text { from } \\
\text { floor } \\
\text { Center } \mathrm{N} \text { wall, } 7 \mathrm{ft} \text { from floo } \\
\text { Center } \mathrm{W} \text { wall, } 7 \mathrm{ft} \text { from } \\
\text { floor } \\
\text { Center of floor, } 2 \mathrm{ft} \text { from } \mathrm{E} \\
\text { wall } \\
\text { Rail support, } 20 \mathrm{ft} \text { from } \mathrm{S} \\
\text { wall, } 14 \mathrm{ft} \text { from floor } \\
\text { Ceiling beam, } 20 \mathrm{ft} \text { from } \mathrm{S} \\
\text { wall, } 5 \mathrm{ft} \text { from W wall } \\
1 \mathrm{ft} \mathrm{S}, 6 \mathrm{ft} \mathrm{E} \text { of } \mathrm{NW} \text { corner }\end{array}$} \\
\hline VT201 & 0.10 & 0.45 & covered port & \\
\hline VT202 & 0.10 & 0.45 & covered port & \\
\hline VT203 & 0.10 & 0.45 & covered port & \\
\hline VT204 & 0.10 & 0.45 & covered port & \\
\hline VT205 & 0.10 & 0.45 & covered port & \\
\hline VT206 & 0.10 & 0.45 & covered port & \\
\hline VT207 & 0.10 & 0.45 & covered port & \\
\hline VT208 & 0.19 & 0.86 & covered port & \\
\hline VM200 ( $\mathrm{H}_{2} \mathrm{O}$ blank $)$ & 1.0 & & & \\
\hline VM201 (equip.rinsate) & 1.0 & & & \\
\hline
\end{tabular}
Fig. 4.

aSamples designated " $M$ " are dust or debris; " $T$ " samples are smears. Locations of samples are șhown on

bConcentrations of beryllium in $\mu \mathrm{g} / \mathrm{ft}^{2}$ are calculated using the sample size.

cSample numbers beginning at VT200 were split and also analyzed for beta-gamma and alpha radioactivity (see text). 



\section{INTERNAL DISTRIBUTION}

\author{
1. B. A. Berven \\ 2. K. J. Brown \\ 3. R. F. Carrier \\ 4. W. D. Cottrell \\ 5-10. R. D. Foley \\ 11. H. O. Hultgren \\ 12-14. C. A. Johnson \\ 15. M.E. Murray \\ 16. P. T. Owen \\ 17. D. A. Roberts
}

\author{
18. R. E. Rodriguez \\ 19 -22. R. E. Swaja \\ 23. M. S. Uziel \\ 24. J. K. Williams \\ 25. Central Research Library \\ 26-27. Laboratory Records \\ 28. Laboratory Records-RC \\ 29. ORNL Patent Section \\ 30. ORNL Technical Library, Y-12 \\ 31-36. MAD Records Center
}

\section{EXTERNAL DISTRIBUTION}

37. James J. Fiore, Director, Office of Eastern Area Programs, Office of Environmental Restoration, U.S. Department of Energy, 4th Floor, 656 Quince Orchard Rd., Gaithersburg, MD 20878

38. L. K. Price, Director, Former Sites Restoration Division, Oak Ridge Field Office, U.S. Department of Energy, P.O. Box 2001, Oak Ridge, TN $37831-8723$

39-139. A. R. Seepo, Department of Energy, Building M2-Warehouse, 2401 River Road, Schenectady, New York 12301-1069

140. James W. Wagoner II, Director, Division of Off-Site Programs, Office of Eastern Area Programs, Office of Environmental Restoration, U.S. Department of Energy, 4th Floor, 656 Quince Orchard Rd., Gaithersburg, MD 20878

141. A. Wallo III, Department of Energy, Environmental Guidance Division (EH-232) 1000 Independence Avenue, Washington DC 20585

142-143. W. A. Williams, Designation and Certification Manager, Division of Off-Site Programs, Office of Eastern Area Programs, Office of Environmental Restoration, U.S. Department of Energy, 4th Floor, 656 Quince Orchard Rd., Gaithersburg, MD 20878

144. C. D. Young, Office of Technical Services, Roy F. Weston, Inc., 12800 Middlebrook Road, Suite 207, Germantown, MD 20874

145-147. Office of Scientific and Technical Information, U.S. Department of Energy, P.O. Box 62, Oak Ridge, TN 37831 